\title{
Effect of different levels of dried sweet orange (Citrus sinensis) peel on broiler chickens growth performance
}

\author{
Abbas Ebrahimi ${ }^{1}$, Ali Ahmad Alaw Qotbi ${ }^{2}$, Alireza Seidavi² ${ }^{2}$ Vito Laudadio ${ }^{3}$ and Vincenzo \\ Tufarelli ${ }^{3}$
}

'Young Researchers Club, Rasht Branch, Islamic Azad University, Rasht, Iran, '2Department of Animal Science, Rasht Branch, Islamic Azad University, Rasht, Iran, ${ }^{3}$ Department of DETO - Section of Veterinary Science and Animal Production, University of Bari »Aldo Moro«, Valenzano 70010, Bari, Italy

\begin{abstract}
The trial was conducted to evaluate the effect of different levels of dried sweet orange (Citrus sinensis) peel on growth performance in broilers. A total of 400 male broiler chicks (Ross-308) were randomly allocated to treatments varying in supplemental DSOP. The dietary groups consisted of five diets fed for 42 days: control diet without feed additive, diet containing $1.5 \%$ feed additive only in starter phase, diet containing $1.5 \%$ feed additive during whole period (starter + grower), diet containing $3 \%$ feed additive only in starter phase, diet containing $3 \%$ feed additive during whole period. The growth responses achieved by broilers from all groups complied with the standards. However, adding up to $3 \%$ DSOP in diet seems to depress feed intake, body weight gain increasing feed conversion ratio of both starter and growing broilers. Conversely, DSOP in the proportion of $1.5 \%$ of feed seems to promote feed intake and weight gain in the period between the 1-21 days of age, indicating that DSOP can constitute a useful additive in the feeding of broilers. Further research is needed to assess the effects of DSOP to improve its suitability as a feed resource for poultry production.
\end{abstract}

Keywords: sweet orange peel, broiler, growth traits

Abbreviations: DSOP: dried sweet orange peel; DSOP-0: control diet without feed additive; DSOP-1.5S: diet containing $1.5 \%$ feed additive only in starter period; DSOP-1.5W: diet containing $1.5 \%$ feed additive in whole period (starter+growing); DSOP-3S: diet containing 3\% feed additive only in starter period; DSOP-3W: diet containing $3 \%$ feed additive in whole period (starter+growing); SEM: standard error of the means

Archiv Tierzucht 56 (2013) 2, 11-17

doi: $10.7482 / 0003-9438-56-002$

Corresponding author:

Alireza Seidavi; email: alirezaseidavi@iaurasht.ac.ir

Department of Animal Science, Rasht Branch, Islamic Azad University, Rasht, Iran

() 2013 by the authors; licensee Leibniz Institute for Farm Animal Biology (FBN), Dummerstorf, Germany. This is an Open Access article distributed under the terms and conditions of the Creative Commons Attribution 3.0 License (http://creativecommons.org/licenses/by/3.0/).
Received: 27 April 2012 Accepted: 12 July 2012 Online: 8 February 2013 


\section{Introduction}

Poultry meat is a popular and versatile proteinaceous food consumed in large amount relative to other meats (Moumeni 2001). Optimal management and nutrition can reduce costs and economize productions to offer higher quality products to consumers especially in semi-arid areas (Pope \& Emmert 2001, Laudadio et al. 2009). Further, due to concerns of bacterial resistance, the use of antibiotics has been under scrutiny. Different antibiotics may be used simultaneously or intermittently in poultry diet. Ban the use of antibiotics as growth promoters, leading them to find alternatives in animal feeding (Callaway et al. 2008, Dibaji et al. 2012, Aziz Mousavi et al. 2012). One of these compounds, essential oils from plants can be used as growth promoters in broilers diet. Sweet orange (Citrus sinensis) is one of the most important and oldest horticulture products in many tropical and sub-tropical areas. Further, orange peels are a primary by-product produced by the fruit processing industry, so attempts were made to use DSOP as natural feed additive, and even as medicinal supplement for animals (Callaway et al. 2008). Chemically, sweet oranges are valuable source of vitamin C as well as energy (Hasin et al. 2006, Yang et al. 2011). Vitamin C or polyphenols increased antioxidant enzymes in red blood cells (Dragsted et al. 2001). In many cases, its skin is even more nutritious than Citrus sinensis. Sweet orange peel contains high concentrations of phenol (Manthey 2004). Previous studies have found that sweet orange and other citrus are also effective in lowering blood cholesterol (Trovato et al. 1996, Parmar \& Kar 2008). Oluremi et al. (2006) reported that sweet orange rind can be used in broiler up to $15 \%$ level without any adverse effect on growth performance. Mourao et al. (2008) reported that adding citrus pulp reduced daily gain when birds fed $10 \%$ citrus pulp compared with the control diet; conversely, feed intake increased in broilers fed with $5 \%$ or $10 \%$ of citrus pulp, which resulted in higher feed efficiency in birds fed diets contained $10 \%$ of citrus pulp. Therefore, this study was performed to examine the effect of different levels of DSOP as feed additive on performance of broiler chickens.

\section{Materials and methods}

\section{Animals and dietary treatments}

The study was carried out in a poultry farm situated in Sowme'eh Sara in Gilan Province, Iran. The trial lasted 42 days during 2011 and used scaffoldings, pens with dimensions of $2 \times 1 \mathrm{~m}$ and height of $1 \mathrm{~m}$ installed, and each pen was assigned to a repeat. In preparation to trial, poultry facility was carefully cleaned and rinsed using pressurised water in order to disinfect poultry facilities. After drinkers and feeders installation and $24 \mathrm{~h}$ before broilers allocation, the hall was gasified. These procedures were repeated before each of the four replicates.

Four hundred day-old chicks (Ross-308) from a commercial hatchery were raised in a conventional environment. The study was conducted in a completely randomised design with five treatments. Each diet (treatment) was replicated four times, with each replicate comprising one pen of 20 birds. The average body weight of broilers was on average $43.5 \mathrm{~g}$. Chicks were vaccinated following the standard vaccination schedule, and in order to reduce the stress caused by vaccination to birds, $24 \mathrm{~h}$ before and after vaccination, a multi-electrolyte solution was added in drinking water. Poultry facility had thermostatically controlled curtains and cross-ventilation as well as lighting program (Laudadio et al. 2012). Pens were equipped 
with a pan feeder, a manual drinker and wood shavings. Drinkers were regularly washed to prevent with faecal and microbial contaminations.

A two phase feeding regime consisting of starter (1 to 21 day) and grower (22 to 42 day) was used in the study. Experimental treatments included: DSOP-0 - control diet without feed additive, DSOP-1.5S - diet containing $1.5 \%$ feed additive only during the starter phase, DSOP-1.5W - diet containing $1.5 \%$ feed additive during the whole period (starter + grower), DSOP-3S - diet containing $3 \%$ feed additive only during the starter phase, DSOP-3W - diet containing $3 \%$ feed additive during the whole period (starter + grower). The DSOP was added to basal diet at the expense of ground corn in the experimental diets. Proximate chemical composition of DSOPs is reported in Table 2. Diets were formulated to meet or exceed broiler nutrients' requirements (NRC 1994). Feed and water were provided ad libitum. Samples of DSOP and diet were ground in a hammer mill with a $1 \mathrm{~mm}$ screen and analysed in triplicate for dry matter, ash, crude protein $(\mathrm{N} \times 6.25)$, crude fibre and ether extract according to the methods of AOAC (2000). Ingredient and chemical composition of the basal diets are shown in Tables 3 and 4, respectively. The body weight and feed intake by replicate were determined weekly for all birds. Average daily body weight gain, average total feed intake and feed conversion ratio were then calculated.

Table 1

Proximate chemical composition of DSOP

\begin{tabular}{lr}
\hline Item, $\mathrm{g} / \mathrm{kg}$ & DSOP \\
\hline Dry matter & 880.0 \\
Crude protein & 54.6 \\
Crude fibre & 100.0 \\
Total carbohydrates & 635.0 \\
Ether extract & 20.0 \\
Ash & 70.0 \\
Calcium & 11.0 \\
Phosphorus & 0.5 \\
\hline
\end{tabular}

Table 2

Ingredient composition of basal starter and grower diets fed to broilers

\begin{tabular}{lcc}
\hline Ingredient, \% as fed-basis & Starter diet (1-21 days) & Grower diet (22-42 days) \\
\hline Corn & 54.32 & 58.69 \\
Soybean meal, 48 \% crude protein & 39.43 & 31.87 \\
Corn oil & 2.16 & 5.83 \\
Dicalcium phosphate & 2.05 & 1.68 \\
Oyster shell & 0.90 & 0.79 \\
Vitamin-mineral premix & \\
Sodium chloride & 0.50 & 0.50 \\
DL-Methionine & 0.37 & 0.37 \\
L-Lysine & 0.20 & 0.22 \\
\end{tabular}

'DSOPs were added to basal diet at the expense of ground corn in the experimental diets. ${ }^{2}$ Supplied per kg of diet: Vitamin A $12000 \mathrm{IU}$, Vitamin E $10 \mathrm{mg}$, Vitamin D $2200 \mathrm{IU}$, niacin $35 \mathrm{mg}$, D-pantothenic acid $12 \mathrm{mg}$, riboflavin $3.63 \mathrm{mg}$, pyridoxine $3.5 \mathrm{mg}$, thiamine $2.4 \mathrm{mg}$, folic acid $1.4 \mathrm{mg}$, biotin $0.15 \mathrm{mg}$, Vitamin B $0.03 \mathrm{mg}$, Manganese $60 \mathrm{mg}$, Zinc $40 \mathrm{mg}$, Iron $1280 \mathrm{mg}$, Copper $8 \mathrm{mg}$, lodine $0.3 \mathrm{mg}$, Selenium $0.2 \mathrm{mg}$ 
Table 3

Chemical analysis of experimental diets fed to broilers during the experimental periods

\begin{tabular}{lcc}
\hline Item & Starter diet (1-21 days) & Grower diet (22-42 days) \\
\hline Metabolisable energy, kcal/kg of diet & 2900 & 3200 \\
Crude protein, \% & 22.16 & 19.20 \\
Lysine, \% & 1.15 & 0.96 \\
Methionine, \% & 0.50 & 0.48 \\
Met + Cys, \% & 0.83 & 0.78 \\
Threonine, \% & 0.79 & 0.71 \\
Calcium, \% & 1.00 & 0.85 \\
Phosphorus available, \% & 0.50 & 0.42 \\
Dietary cation-anion balance, $\mathrm{mEq} / \mathrm{kg}$ of diet & 236 & 202 \\
\hline
\end{tabular}

Table 4

Effect of different levels of DSOP on broilers growth performance

\begin{tabular}{lccrrrr}
\hline Treatment & DSOP-0 & DSOP-1.5S & DSOP-1.5W & DSOP-3S & DSOP-3W & SEM \\
\hline Total feed intake, g/bird & & & & & & \\
1-21 days & $1065.8^{\mathrm{a}}$ & $1074.03^{\mathrm{a}}$ & $1047.50^{\mathrm{a}}$ & $970.90^{\mathrm{b}}$ & $1048.44^{\mathrm{a}}$ & 8.38 \\
22-42 days & $3523.8^{\mathrm{b}}$ & $3730.75^{\mathrm{a}}$ & $3564.58^{\mathrm{b}}$ & $3536.08^{\mathrm{b}}$ & $3529.63^{\mathrm{b}}$ & 29.38 \\
1-42 days & $4589.5^{\mathrm{bc}}$ & $4804.78^{\mathrm{a}}$ & $4612.08^{\mathrm{b}}$ & $4506.98^{\mathrm{c}}$ & $4578.06^{\mathrm{bc}}$ & 29.16 \\
Average daily gain, g/day/bird & & & & & & \\
1-21days & $37.45^{\mathrm{a}}$ & $34.35^{\mathrm{ab}}$ & $33.87^{\mathrm{ab}}$ & $32.77^{\mathrm{b}}$ & $30.66^{\mathrm{b}}$ & 1.25 \\
22-42days & $79.25^{\mathrm{a}}$ & $81.95^{\mathrm{a}}$ & $80.26^{\mathrm{a}}$ & $84.64^{\mathrm{a}}$ & $74.35^{\mathrm{a}}$ & 2.39 \\
1-42 days & $58.35^{\mathrm{a}}$ & $58.15^{\mathrm{a}}$ & $57.06^{\mathrm{a}}$ & $58.71^{\mathrm{a}}$ & $52.51^{\mathrm{b}}$ & 1.38 \\
Feed conversion ratio, g/g & & & & & & \\
1-21days & $1.26^{\mathrm{b}}$ & $1.37^{\mathrm{b}}$ & $1.33^{\mathrm{b}}$ & $1.28^{\mathrm{b}}$ & $1.53^{\mathrm{a}}$ & 0.03 \\
22-42 days & $2.21^{\mathrm{a}}$ & $2.32^{\mathrm{a}}$ & $2.17^{\mathrm{a}}$ & $2.05^{\mathrm{a}}$ & $2.43^{\mathrm{a}}$ & 0.13 \\
1-42 days & $1.74^{\mathrm{bc}}$ & $1.85^{\mathrm{ab}}$ & $1.75^{\mathrm{bc}}$ & $1.67^{\mathrm{c}}$ & $1.98^{\mathrm{a}}$ & 0.05 \\
\hline
\end{tabular}

$a, b, c$ Means within a row with the same letter are not significantly different $(P<0.05)$.

\section{Statistical analysis}

Data recorded for broilers' growth performance were statistically analysed using the one-way analysis of variance (ANOVA). Each treatment with four replications was used as completely randomised block design, and each pen was an experimental unit. Statistics were carried out using SAS v8 (SAS Institute Inc., Cary, NC, USA). If occurred, Duncan's multiple range test was applied to compare the differences between the means (Steel et al. 1997).

\section{Results}

Results on feed intake, mean daily body weight gains and feed conversion ratio are presented in Table 4. In comparison with the control group, average feed consumption of group fed the diet supplemented with 1.5\% DSOP in starter phase developed in a better way during the whole rearing period. Conversely, the incorporation up to $3 \%$ DSOP in the mixtures resulted in the lower feed intake reflected by a decreasing in growth and by a much higher feed conversion ratio. Additionally, during the entire growing period, the better daily body 
weight gain was related to treatment including $3 \%$ DSOP during the starter phase, whereas the significant lowest gains were achieved in broilers fed $3 \%$ DSOP for the whole growth period (1-42 days). According to our results, there were significant $(P<0.05)$ differences for the average feed conversion ratio between the different dietary treatments. In particular, the significant lowest values of feed conversion ratio were related to broilers fed dietary treatment including DSOP at the rate of $3 \%$ only during the starter phase.

\section{Discussion}

Findings from this study showed that the average feed intake during different periods of growth in broilers fed diet including 1.5\% DSOP in starter phase was higher than other dietary treatments, conversely feeding 3\% DSOP in the same phase resulted in lower feed consumption when compared to the other treatments. These results are in agreement with the findings of Oluremi et al. (2010) which used fermentation products of Citrus sinensis peel at the rate of $30 \%$ in starter diets of broiler as substitute to corn. In a previous study, Al-Kassie (2008) found that when fennel and rosemary powders were used as feed additives in broiler rations resulted in same growth trend compared to control unsupplemented diet. Moreover, Al-Ankari et al. (2004) when included mint powder in chicks' rations found an improvement in terms of feed consumption. Conversely, Barreto et al. (2008) stated that when broilers were fed diets containing a mixture of extracts from wild marjoram, cloves and cinnamon reported a depression of feed intake if compared to birds fed conventional antibiotics as growth promoter. The same trend is reported by Ghazalah \& Ali (2008) who used rosemary leaf powder as feed additive in broiler diet.

In our study, the lower trend in feed intake was recorded for broilers fed $3 \%$ DSOP during the whole rearing period. The reduction in feed consumption rate in $3 \%$ DSOP treatment when compared with other treatments could be attributed to a decrease in ration palatability when diet included Citrus sinensis peel and, further it could be also due to residual anti-nutritional substances (such as oxalate, saponins, tannins, phytates) in peels. In addition, the high crude fibre level contained in the orange peel can determine negative effects on broilers performance (Murray 1998, Ayed et al. 2011, Soltani et al. 2012). Oluremi et al. (2006) reported that sweet orange rind can be used to replace maize in the diet of broiler up to $15 \%$ level without any adverse effect on performance. Florou-Paneri et al. (2001) reported that use of up to $6 \%$ digestible crude protein in laying quails diets had no significant adverse effect on performance. Substances having antibiotics property affect the body weight gain through different mechanisms. First, they decrease the amount of intestinal harmful microorganisms and in turn provide the possibility of nutrients absorbed by poultry (Nannapaneni et al. 2008). Further, detrimental microorganisms stimulate the immune system of birds, and thus nutrients instead applied to build protein and muscle are used in the immune system of animals. As well establish antibiotic can enhance growth in animals (Apata 2009). Another factor that affects weight gain are every factors that expose animal health by weakening of the body and tissues erosion performance caused to reduced growth rate (Apata 2009). Gabriel et al. (2006) found that leaf powder and extract oil of Artemisia annua had anti coccidiosis property and reduces the number of oocytes per gram of faeces as well as daily weight gain in broilers, which is consistent with the results of the 
present study. The effects of the experimental diets on feed conversion ratio of broilers were significant different among dietary treatments. As well know feed conversion ratio is strictly related to the daily body weight gain and feed intake. Therefore, the difference obtained in the present trial can be related to these two factors. Moreover, also physiological factors can affect the performance responses in poultry. Among these factors, we can pointed out that, although in poultry the sense of smell and taste is weaker in comparison with other species, it is clear that compounds in the feed intake of the flavoured diet change can occur (Perdok et al. 2003, Isabel \& Santos 2009). As a result from our study, the dietary inclusion of DSOP as feed additive did not depress broiler growth below the acceptable range of weight.

According to results we can conclude that DSOP influenced growth traits of broiler chicks in different development periods, indicating that DSOP at rate of $1.5 \%$ can constitute a useful additive in the feeding of broilers especially during the starter phase. However, further research is needed to assess the effects of DSOP to improve its suitability as a feed resource and growth promoter in poultry production.

\section{Acknowledgements}

This manuscript was obtained from MSc Thesis of Abbas Ebrahimi at Islamic Azad University, Rasht Branch, Rasht, Iran. We are grateful to the Islamic Azad University, Rasht Branch, Rasht, Iran and Mrs Zohreh Pourhossein and Mr Nariman Miraalami for support.

\section{References}

Al-Ankari AS, Zaki MM, Al-Sultan SI (2004) Use of Habek Mint (Mentha longifolia) in Broiler Chicken Diets. Int J Poult Sci 3, 629-634

Al-Kassie GAM (2008) The Effect of Anise and Rosemary on Broiler Performance. Int J Poult Sci 7, 243-245

AOAC (2000) Official methods of analysis. 17th ed. Association of Official Analytical Chemists. Washington DC, USA

Apata DF (2009) Antibiotic Resistance in Poultry. Int J Poult Sci 8, 404-408

Ayed HM, Zghal I, Rekik B (2011) Effect of sepiolite supplementation on broiler growth performance and carcass yield. Res Opin Anim Vet Sci 1, 375-378

Aziz Mousavi SMA, Seidavi AR, Dadashbeiki M (2012) Effect of different levels of synbiotics on carcass characteristics of broiler. Res Opin Anim Vet Sci 2, 161-165

Barreto MSR, Menten JFM, Racanicci AMC, Pereira PWZ, Rizzo PV (2008) Plant Extracts used as Growth Promoters in Broilers. Rev Bras Cienc Avic 10, 109-115

Callaway TR, Carroll JA, Arthington JD, Pratt C, Edrington TS (2008) Citrus Products Decrease Growth of E. coli 0157: $\mathrm{H7}$ and Salmonella Typhimurium in Pure Culture and in Fermentation with Mixed Ruminal Microorganisms In Vitro. Foodborne Pathog Dis 5, 621-627

Dibaji SM, Seidavi A, Asadpour L (2012) Effect of dietary inclusion of the synbiotic Biomin IMBO on broilers' some blood metabolites. Res Opin Anim Vet Sci 2, 10-13

Dragsted LO, Young JF, Loft S, Sandstrom B, Nesaretnam K, Packer L (2001) Biomarkers of oxidative stress and of antioxidative defense: relationship to intervention with antioxidant-rich foods. In: Nesratnem K, Packer $\mathrm{L}$ (eds.) (2001) Micronutrients and health: molecular biological mechanisms, Danish Food Administration, Søborg, Denmark, 272-278

Florou-Paneri P, Babidis V, Kufidis D, Christaki E, Spais AB (2001) Effect of feeding dried citrus pulp on quail laying performance and some egg quality characteristics. Arch Geflügelk 65, 178-181 
Gabriel I, Lessire M, Mallet S, Guillot JF (2006) Microflora of the digestive tract: critical factors and consequences for poultry. Worlds Poult Sci J 62, 499-511

Ghazalah AA, Ali AM (2008) Rosemary Leaves as a Dietary Supplement for Growth in Broiler Chickens. Int J Poult Sci 7, 234-239

Hasin BM, Ferdaus AJM, Islam MA, Uddin MJ, Islam MS (2006) Marigold and Orange Skin as Egg Yolk Color Promoting Agents. Int J Poult Sci 5, 979-987

Isabel B, Santos $Y$ (2009) Effects of dietary organic acids and essential oils on growth performance and carcass characteristics of broiler chickens. J Appl Poult Res 18, 472-476

Laudadio V, Tufarelli V, Dario M, D'Emilio FP, Vicenti A (2009) Growth performance and carcass characteristics of female turkeys as affected by feeding programs. Poult Sci 88, 805-810

Laudadio V, Dambrosio A, Normanno G, Khan RU, Naz S, Rowghani E, Tufarelli V (2012) Effect of reducing dietary protein level on performance responses and some microbiological aspects of broiler chickens under summer environmental conditions. Avian Biol Res 5, 88-92

Manthey JA (2004) Fractionation of Orange Peel Phenols in Ultrafiltered Molasses and Mass Balance Studies of Their Antioxidant Levels. J Agric Food Chem 52, 7586-7592

Moumeni T (2001) Herbal extracts, Farhad Reza Publication, 382

Mourao JL, Pinheiro VM, Prates JAM, Bessa RJB, Ferreira LMA, Fontes CMGA, Ponter PIP (2008) Effect of Dietary Dehydrated Pasture and Citrus Pulp on the Performance and Meat Quality of Broiler Chickens. Poult Sci 87, 733-743

Murray MT (1998) Quercetin: Nature's antihistamine, Better Nutrition, 60, 10

Nannapaneni R, Muthaiyan A, Crandall PG, Johnson MG, O'Bryan CA, Chalova VI, Callaway TR, Carroll JA, Arthington JD, Nisbet DJ, Ricke SC (2008) Antimicrobial Activity of Commercial Citrus-Based Natural Extracts Against Escherichia coli 0157:H7 Isolates and Mutant Strains. Foodborne Path Dis 5, 695-699

NRC (1994) Nutrient Requirements of Poultry, 9th rev. ed., National Research Council, Washington, USA

Oluremi OIA, Okafor FN, Adenkola AY, Orayaga KT (2010) Effect of Fermentation of Sweet Orange (Citrus sinensis) Fruit Peel on its Phytonutrients and the Performance of Broiler Starter. Int J Poult Sci 9, 546-549

Oluremi OIA, Ojighen VO, Ejembi, EH (2006) The Nutritive Potentials of Sweet Orange (Citrus sinensis) Rind in Broiler Production. Int J Poult Sci 5, 613-617

Parmar HS, Kar A (2008) Antiperoxidative, Antithyroidal, Antihyperglycemic and Cardioprotective Role of Citrus sinensis Peel Extract in Male Mice, Phytother Res 22, 791-795

Perdok H, Langhout P, Van Vugt P (2003) Stimulating appetite. Feed Mix 11, 10-13

Pope T, Emmert JL (2001) Phase-Feeding Supports Maximum Growth Performance of Broiler Chicks from Forty- three to Seventy-one Days of Age. Poult Sci 80, 345-352

Soltani A, Pourreza J, Kheiri F, Faghani M (2012) Effect of partially substituted barley malt on performance, bone ash, calcium and phosphorus of broiler chickens. Res Opin Anim Vet Sci 2, 133-135

Steel RGD, Torrie JH, Dicky DA (1997) Principles and Procedures of Statistics: A Biomertrical Approach, 3rd Edition. McGraw-Hill Series in Probability and Statistics, WCB/McGraw-Hill, New York, USA

Trovato A, Monforte MT, Barbera R, Rossitto A, Galati EM, Forestieri AM (1996) Effects of fruit juices of Citrus sinensis $\mathrm{L}$. and Citrus limon $\mathrm{L}$. on experimental hypercholesterolemia in the rat. Phytomedicine 2, 221-227

Yang XY, Xie JX, Wang FF, Zhong J, Liu YZ, Li GH, Peng SA (2011) Comparison of ascorbate metabolism in fruits of two citrus species with obvious difference in ascorbate content in pulp. J Plant Physiol 168, 2196-2205 